\title{
THE IMPACT OF COVID-19 ON SOCIO ECONOMIC CONDITION OF CITY PEOPLE: LESSONS FROM THE SELECTED KCC AREA
}

\author{
Md. Nazmul Haque ${ }^{1 *}$, Saifullah Bin Ansar ${ }^{1}$, Gitisree Biswas ${ }^{1}$, Md Razzakul Islam ${ }^{1}$ and Abdullah Al \\ Mamun $^{2}$ \\ ${ }^{1}$ Department of Urban and Regional Planning, Khulna University of Engineering \& Technology, Khulna -9203 \\ ${ }^{2}$ Arc Bangladesh Ltd, Dhaka-1207, Bangladesh
}

Received: 04 November 2020

Accepted: 03 December 2020

\begin{abstract}
This paper aims to provide a small-scale quantitative overview about the impact on socio economic condition in lockdown wards of Khulna City Corporation (KCC), Bangladesh due to this pandemic. Online survey for primary data was conducted through 158 respondents and the informants belongs to different types of occupation such as student, govt. employee, businessman etc. Secondary data was obtained from various credential sources. With the socioeconomic stress of COVID-19, people's satisfaction level is measured with well-known index life scale assessment to measure the judgmental component of subjective well-being. This study reveals that $44 \%$ respondents who preferred online based activities which are directly related with online activity and occupation related activities rather than physically involved activities (33\%) due to maintain social distancing. Besides about 46\% maid was suspended due to hygienic concern and 45\% driver was suspended because of the inability of maintenance cost i.e. an economic pressure which has been reflected on all classes of people. According to life scale assessment, 35\% people were slightly dissatisfied and only 1\% of them are extremely satisfied during this situation. It means that maximum of the people allows their living condition to be in the less satisfied range during this pandemic situation. Besides, hospital accessibility has been analyzed among the lockdown wards and it is observed that ward no.-24 whose has good accessibility with $292 \mathrm{~m}$ distance from the locality but poor condition has been observed in ward no.-17. To attenuate these ill socioeconomic conditions, initiatives of inclusive cooperation of different stakeholders should be taken spontaneously.
\end{abstract}

Keywords: COVID-19; KCC; lockdown; Socio-economic condition; Satisfaction with Life.

\section{INTRODUCTION}

The current globalization is facing the greatest challenge of Covid-19 after world war two and causing crucial heath crisis to human life and distortion of livelihood (The Economist Intelligence Unit, 2020). It is Corona virus disease, named as COVID-19 is the $7^{\text {th }}$ corona virus invaded to human life with 1.4 million confirmed cases and over 83,000 deaths worldwide and 213 countries has been still affected (Zhu et al., 2020). WHO announced it as a global pandemic on 11 March 2020 (WHO, 2020). Since COVID-19 is spreading rapidly with physical contact and droplet infection also many often a large portion of patients remain asymptomatic and infect others as well as there's no vaccine yet (Godman, 2020). In this situation the COVID-19 has sparked drastic crisis in socioeconomic sectors and prevention strategies consist of self-isolation, maintaining social-distancing, hygiene measures and travel restrictions (Nicola et al., 2020).

This pandemic situation is no longer limited within health crisis rather it's extending unprecedented devastating impact on social, economic sector and it seems to be dispersing scars in the long run (UNDP, 2020). During this corona outbreak economic sector has faced a tremendous change and in this recent time its implications and impacts are studied as "Coronanomics" (Eichengreen, 2020) also some call it "Black Swan" (Dineri and Çütçü, 2020). Due to this outbreak world experienced an evolving "de-globalization" constraining inter-national lockdown, forestalling typical progressions of products, temporary shut-down of business and production (Barua, 2020).

While the whole world is fighting to mitigate the crucial stress of COVID-19, Bangladesh is not also an exception equally facing this drowning condition at every sector of its life. In the initial stage of lockdown after first corona case identification on 8 March 2020 by (IEDCR (Institute of Epidemiology, Disease Control and Research), 2020) industrial factories, offices and healthcare facilities in both public and private sectors got shut down (Shammi et $a l ., 2020)$ eventually their functionality got disrupted. It has been found that the livelihood of workers in the formal economy will be greatly impacted, so there can be no question that the informal sector with 50 million of workers according to (BBS), will be hit even harder (Islam and Divadkar, 2020). A study found that households encountered a 29\% declination in income due to Covid-19 and a 34\% decline in income in Dhaka Metro (Ali and Nazrul, 2020). As a result, within the first ten days of government lockdown, $6 \%$ of all households became fully jobless and $50 \%$ of households lost at least one-third of their income by affecting the livelihood of lower income and lower middle-income people and presenting them to the impeding impacts of this financial defeat and pushing

*Corresponding Author: nhaque13@urp.kuet.ac.bd

https://www2.kuet.ac.bd/JES/ 
them to the point of no recuperation (Ali and Nazrul, 2020). It is inevitable that a compassionate humanitarian and socioeconomic crisis in a developing country like Bangladesh will occur during a pandemic producing cumulative results of a number of shortcomings that are likely to end in the worst results (Truog et al., 2020)

Khulna, the $3^{\text {rd }}$ largest city in Bangladesh has not been escaped from the devastating prevalence of corona virus. Here total 15602 cases have been identified as well as the total number of deaths 286 in the Khulna division during the pandemic which implies the fatality rate of Khulna division is 1.63\% (Bangladesh Sangbad Sangstha, 2020), (Molla, 2020). Except the fatality impact of corona virus, its macabre invasion to the economic as well as living condition has impacted negatively. Due to lockdown, Mongla sea-port and Beanpole border was closed also Khulna city was disconnected to the central Dhaka city caused supply chain and micro economy of Khulna city to be extensively affected resulting price hike of commodities. This study was designed in focusing the impact and implications of livelihood condition of people centering lockdown wards in KCC (Khulna City Corporation). The concept of studying these particular wards' socioeconomic and living condition was to investigate the grassroot level scenario in this aspect because any global crisis like COVID-19 starts dispersing its longstanding scars through hitting up the living condition at local level, also to get a quite similar scenario which may be helpful to represent the total impact on living standard in KCC during corona outbreak. Ward no.- 9 and 10 both cover mixed land use including variation of living standard in slum and non-slum area. Further, ward no.- 29 also covers mixed land use of educational, commercial services might be cooperative to investigate socioeconomic situation faced after pandemic situation (Haque et al., 2018).

This study aims to examine the change in socio economic condition impacted by COVID-19 outbreak in the particular three wards which are shown in the figure 1 of Khulna City Corporation. Many of the studies have published on the epidemiologic, demographic, economic, health and clinical issues of this outbreak in international and national level. But no study has been done yet on the livelihood conditions influenced by socioeconomic factors in KCC in the very regional level. Hence this study might encourage decision makers to realize the potential vulnerability of human life during this Covid-19 in Khulna city also be able to inspire the local authority to initiate some policy measures.

\section{METHODOLOGY}

\subsection{Study Area}

Khulna City Corporation is the 3rd largest city of Bangladesh who has Mongla port which is the 2nd entry port of Bangladesh. Khulna City Corporation is located beside Rupsha and Bhairab Rivers. This city corporation is consisted with 31 number of wards. For this research purpose only, lockdown wards (Figure 1) were selected after consulting with experts to judge the socio-economic condition. Ward no.- 9, 17 and 24 had been lockdown due to prevent the spreading of virus infected patients (The Daily Star, 2020). Besides total 9 wards $(8,14,16,18,19$, $21,22,28,30$ ) had been declared as red zones (Molla, 2020). Different types of occupational people live in those areas from some day laborers to high ranked persons so a challenging scenario has been observed during lockdown situation (Haque et al., 2018; 2019).

\subsection{Data Collection}

According to the objective the livelihood data was collected through online based survey. To conduct survey, a questionnaire on the basis of livelihood characteristics was designed with the opinion of experts. The questionnaire was tabulated in the Google doc form. The survey was conducted from 3 August to 9 August 2020 within different groups of social media, WhatsApp etc. as well as random sampling method was conducted to collect data. 158 respondents participated in this research process. After collecting data, Excel-2016 has been used to conduct analysis as well as SPSS-23 version has also been used. To measure the accessibility of hospital in the study area, the location of this facility was collected from google earth pro.

\subsection{Accessibility Analysis}

The accessibility was analyzed by using the "Near" tool in Arc GIS 10.5. Centroids of wards were calculated by performing "Add Geometric Attribute" tool. Besides, the Euclidean distance between centroid of wards and the hospitals was measured by using "Near" tool.

\subsection{Method of Satisfaction with Life Scale (SWLS)}

This research would provide quite future interpretation depending on the quantitative study done on the current socioeconomic factor influencing livelihood status and associating life satisfaction as well as subjective wellbeing during pandemic. The subjective well-being considers two broad aspects including i) Emotional which can differentiate between positive and negative affect (Diener, 1984) and ii) Cognitive which is considered as life 
satisfaction (Andrews and Withey, 1976). Diener, Emmons, Larsen developed the Satisfaction with Life Scale (SWLS) in 1985 which consists of five statements with psychometric characteristics (Pavot and Diener, 1993) to assess the meaning of life satisfaction by finding difficulties with the concept of questioning people about their lives (Diener et al., 1985). Nowadays it has become a popular instrument for the easily utilization and also for measuring well-being life satisfaction of the city people during Covid-19 that has been tried to analysis in a quantitative measure of Satisfaction with Life Scale (SWLS). The scale was developed as a way to assess an individual's cognitive judgment of their satisfaction with their life as a whole. This whole satisfaction evaluating the analysis and its result has been presented in three stages. Firstly, assessment of respondent frequency for each statement, secondly composite satisfaction level assessment, thirdly relativity assessment of the satisfaction indicating question's scoring value with the composite value (Pavot et al., 1991). The SWLS is a very simple, short questionnaire made up of only 5 statements. In this study the questions have been asked only depending on the life condition during this Covid-19. Participants completing the questionnaire are asked to judge how they feel about each of the statements using a 7-scale scoring system, with 1 being 'strongly disagree' with the statement and 7 being 'strongly agree' with the statement.

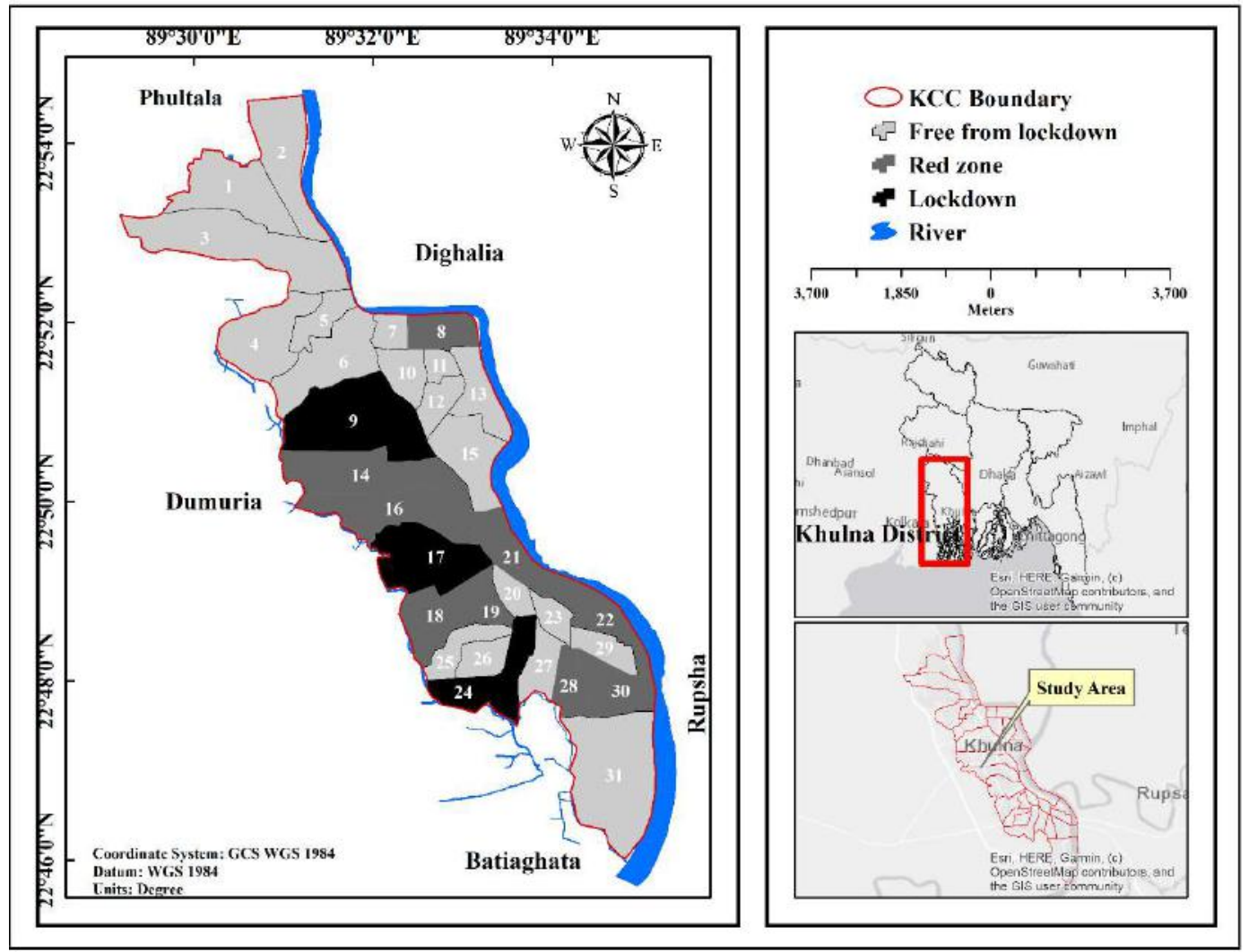

Figure 1: Study area (Black Colored, selected ward which are initially lockdown)

Table 1: Understanding the scores of Satisfaction with Life Scale

\begin{tabular}{cccc}
\hline Score Range & Description & Score Range & Description \\
\hline $31-35$ & Extremely satisfied & $15-19$ & Slightly dissatisfied \\
$26-30$ & Satisfied & $10-14$ & Dissatisfied \\
$21-25$ & Slightly satisfied & $5-9$ & Extremely dissatisfied \\
20 & Neutral & & \\
\hline
\end{tabular}

(Pavot and Diener, 1993)

\section{RESULTS AND DISCUSSION}

\subsection{Demographic Composition of the Respondents}

Figure 2 represents demographic composition of the study area of the 158 respondents to the survey, including $56 \%$ male and the remaining $44 \%$ female. The participants were engaged in different professions as if it was a reflection of the lives of people of different professions in the society. Figure 2(a) highlights the different occupations of the respondents where percentage of private job holders, business and governmental employees is 22, 23 and 18 respectively. Many of the respondents either live in rented house or in their own house. About 58\% 
of the 158 respondents live in rented houses and remaining $42 \%$ have their own houses (Figure 2c). Among of all respondents about $27 \%$ who belongs to this age group 25-34. Besides, those people who were under 45-59 and $60+$ age group, the percentage was 20 and 14 respectively as well as this age classification was established according to BBS age cohort. (Figure $2 \mathrm{~d}$ ).
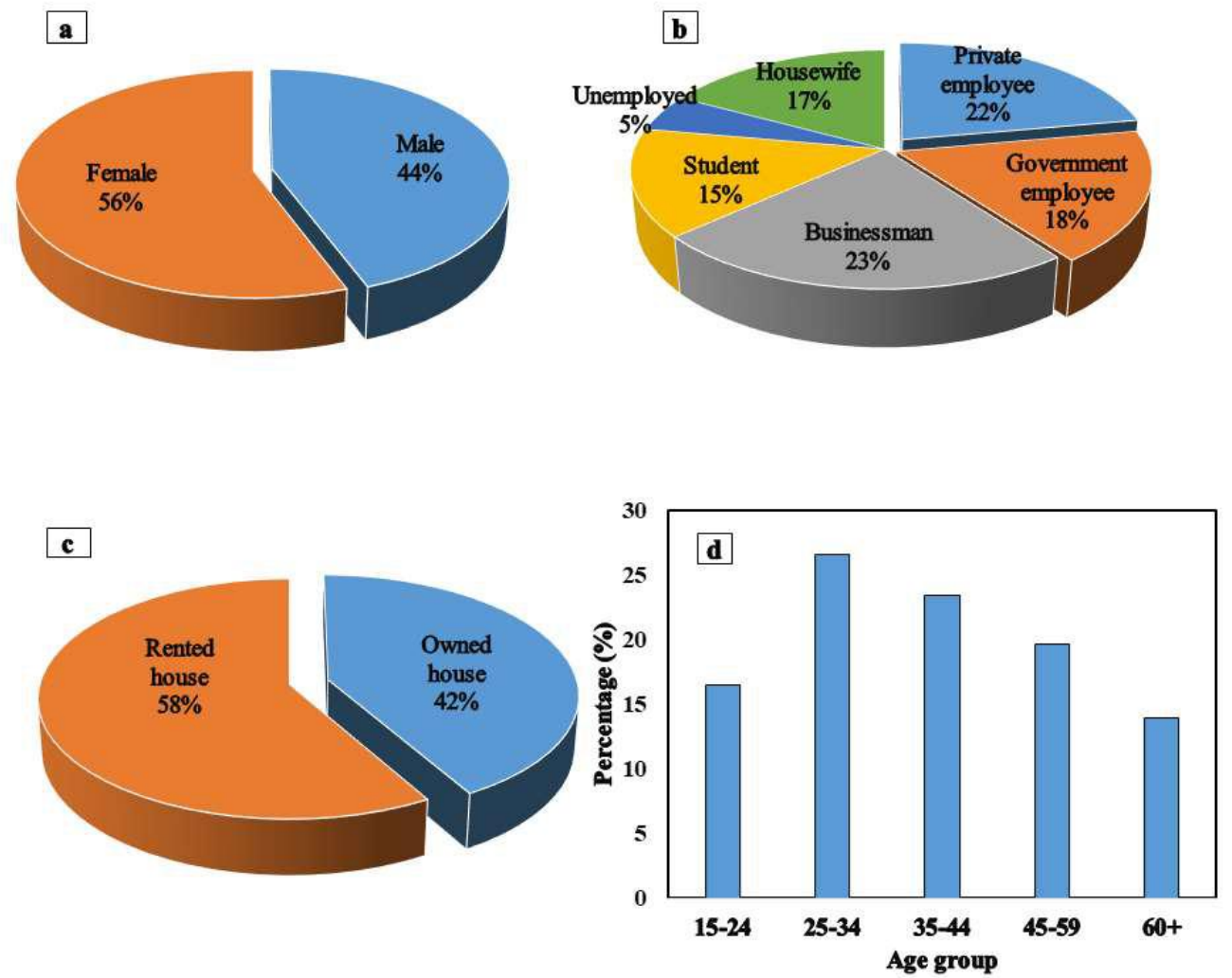

Figure 2: Visual presentation of a) participated gender b) participated respondent occupation c) House ownership status and d) participated age group. Source: Online Survey, 2020

\subsection{Preferable Activities During Pandemic}

Figure 3(a) represents preferable activities for different occupations during pandemic. Govt. employee among of the respondents preferred online based work for ensuring the safety as well as private job holder also preferred that types of work. But some private office did not shut down during lockdown, that's why some people worked their offices physically. Besides, businessman worked physically because trade usually conducts face to face deal and some businessman who faced economical problem during lockdown as they got loss in business. The impact of this loss has been seen on the workers consequently labors/workers was excluded. From the survey data, people of all professions, no matter what their professions, prefer to work online only to protect their health.

\subsection{Worried for Economic Condition}

The respondent expressed their anxiety for financial condition of their family. The people who engaged with business activities were worried about their financial condition. On the other hand, an opposite scenario has been observed for those people who acted as a government employee. Among 158 respondents 55\% people were very worried who were under $60+$ age group i.e. those whose sources of income have been cut off or whose business has been damaged have faced a difficult challenge to support their families financially in the coming months as well as $46 \%$ people were somewhat worried (age group 35-44) this means that those who are losing business, private/ govt. employees who have other sources of income are little bit worried about the economic situation of the family for next month because they are afraid of losing this other source of income (Figure $3 b$ ). 

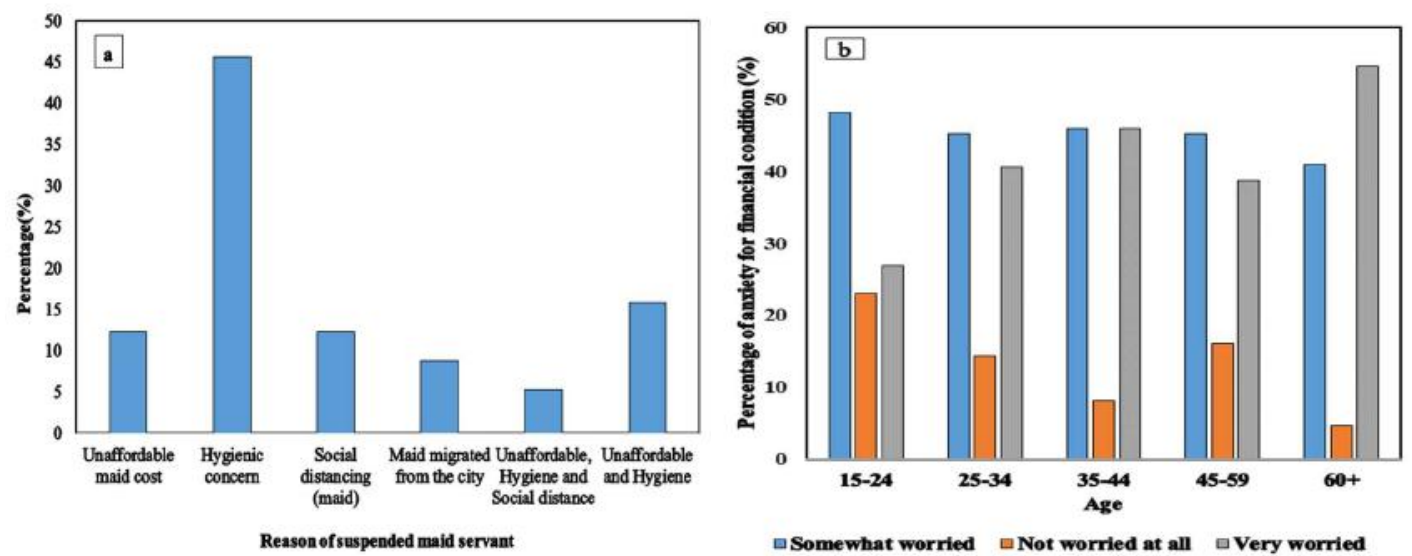

Figure 3: a) Preferable activities during pandemic and b) Worried about financial condition, Source: Online Survey, 2020

\subsection{Status of occupied Members}

Figure 4a represents the status of suspension level for maid servant. After analyzing the survey data regarding maid servant, $46 \%$ maid was suspended during pandemic situation because of hygienic concern. Besides, those people who got loss in business or suspended from job got unable condition to afford the servant (12\%) and also some maid servant migrated to their home land $(9 \%)$ which is another cause of suspension. Besides, to maintain social distance, some people suspended their mad which reflects a sincere concern about health (12\%). Again, from Figure 4b, among 158 respondents only 27 who had private vehicle. The percentage of suspension was $41 \%$ because of maintain social distance as well as unable to afford maintenance cost (45\%). Besides, due to lockdown the owner of the private vehicle did not use during the pandemic situation which is another reason of suspension $(55 \%)$
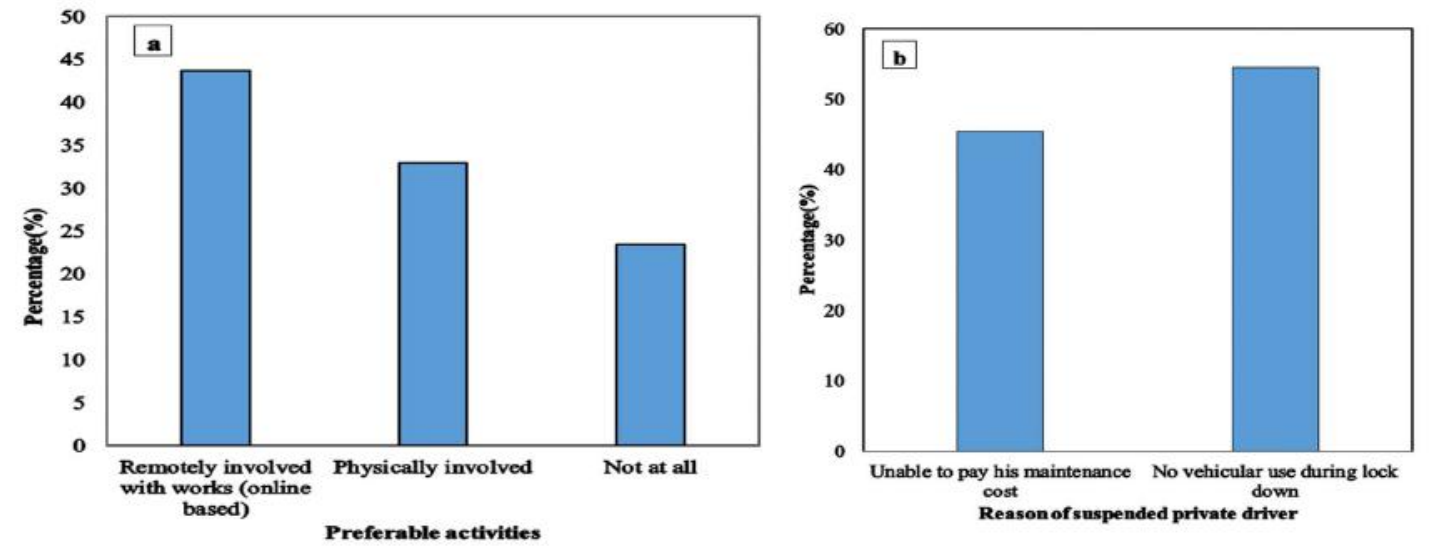

Figure 4: a) Suspension of maid servant and b) Suspension of private driver, Source: Online Survey, 2020

\subsection{Satisfaction with Life Scale (SWLS) Assessment Analysis}

In the first step of the total analysis, amount of the people according to their response category against each statement was extracted through the given scores for each response category (Figure 5a). Here, these statements can be assumed as the indicators for measuring satisfaction. To visualize the classified response category result, a frequency matrix against each statement was represented through Likert chart (Figure 5a). In the Likert chart, result shows that maximum six people strongly agreed in the statement of "If I could live my life over, I would change almost nothing" and minimum three people strongly agreed in "So far I have gotten the important things I want in life" also in "The conditions of my life are excellent" statement. On the other hand, maximum eleven people strongly disagreed in "The conditions of my life are excellent" and then 10 people strongly disagreed to be "So far I have gotten the important things in life" (Figure 5a). 

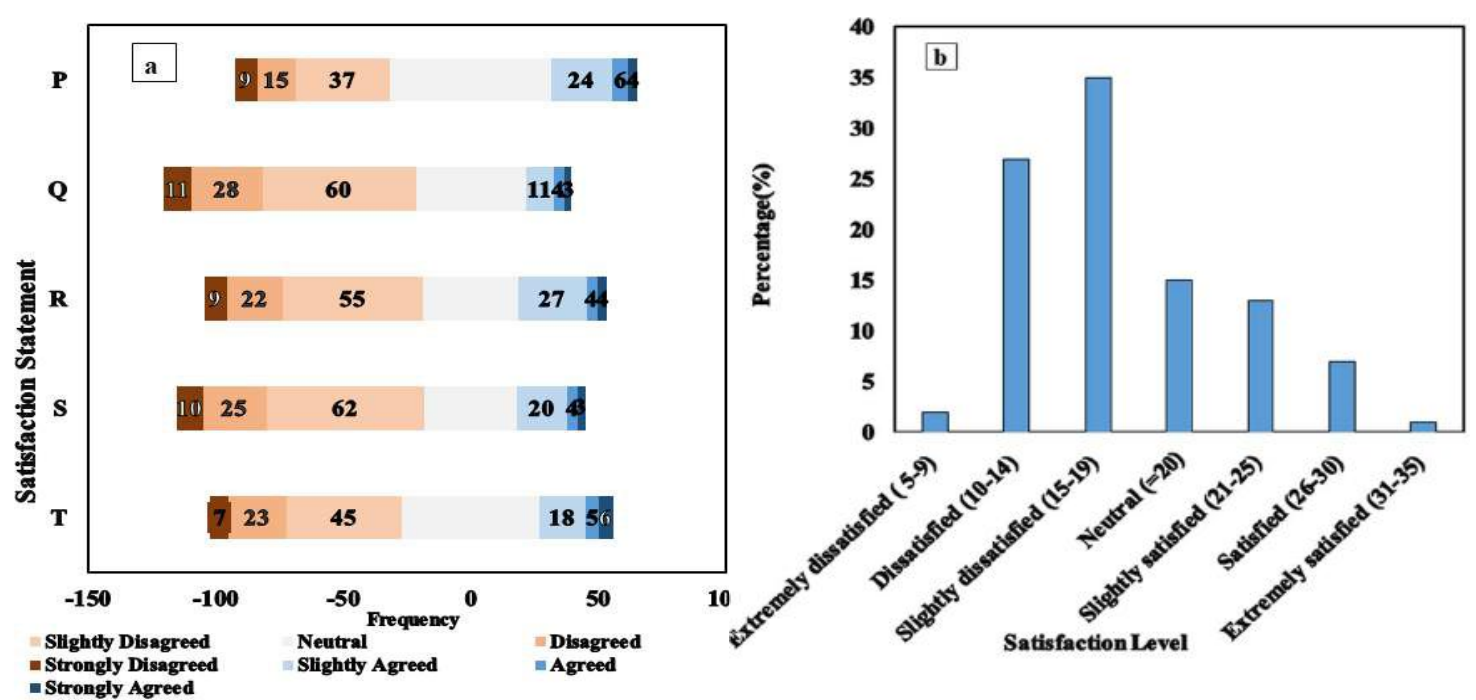

Figure 5: a) Satisfaction scale frequency against each statement ( $\mathrm{P}=$ my life is close to my ideal, $\mathrm{Q}=$ excellent life conditions, $\mathrm{R}=$ satisfied with life, $\mathrm{S}=$ So far I've gotten the important things $\mathrm{I}$ want in life, $\mathrm{T}=\mathrm{If} \mathrm{I}$ could live my life over, I'd change almost nothing and b) Composite satisfaction index. Source: Online Survey, 2020

At least seven people thought themselves to be strongly disagreed in "If I could live my life over, I would change almost nothing". Here it holds noticeable significant value for the statement of "The conditions of my life are excellent" and "So far I have gotten the important things I want in life" because maximum strongly disagreed values and minimum strongly agreed values belong to here. Further, maximum of the people responded to be in neutral satisfaction for the indicator that "In most ways my life is close to my ideal" (Figure 5a). From this representation it can be assumed that very few of the people are less satisfied with the things they have got in life and accept their life condition excellent. But a substantial amount of people quietly accepts their satisfaction with life as well as think their life to be quite ideal. Actually, this Likert chart is the prior representation for the composite satisfaction level measuring index frequency because after adding all the response category score against each statement for all the respondents, summation of those satisfaction value is classified into satisfaction level range and final satisfaction can be measured. These summations of scores was assigned to the provided range of satisfaction level and each respondent were measured according to their own scoring of life satisfaction. After this computation a composite index of frequency number of people in different satisfaction level was derived which is shown with the following bar chart. Finally, all the respondent's satisfaction related response was calculated which is shown with the following bar chart (Figure 5b). From the visual altitude of the bars the most common satisfaction acceptability scored by the respondents against five statements has been understood. Results shows maximum of the people are "slightly dissatisfied" and minimum results came from being "extremely dissatisfied" (Figure 5b). Skew ness of this normal distribution of satisfaction frequency was also tested. Final skew ness result was 0.655 which is more than 0.5 means to be in the moderately positive skew ness range as most of the frequencies are concentrated in the left side of the normal distribution curve.

Reliability test was done to find the inter correlation among the given satisfaction statements with the 5 item sum results. This matrix was created to find how they are related with each other in the composite satisfaction level assessment. Generally, in the satisfaction survey questionnaire the final and composite satisfaction results for each satisfaction indicator are compared by the Cronbach's alpha through inter item correlation. This is actually done to show how satisfaction indicators individually response to the measure of these 5 indicator's sums as well as total satisfaction. Cronbach's alpha is the most common measure of internal consistency ("reliability"). Cronbach's value is available for conduct reliability test.

In the table 3, all the indicators value with the five-item summation value were tested to find the inter item reliability with the measure of Cronbach's alpha. From this five-item analysis Cronbach's Alpha is 0.808. As far this alpha value is considered to be good in reliability if greater than 0.7 . Here the five-item scale's sum reliability with the five statements shows the comparative lower relativity at the indicator of "Life condition is excellent" and "So far gotten the important things". So, it is understood that these two indicators are comparatively less relative to the composite satisfaction. That's why, to find more strong reliability with the life conditions lower results for the indicator "Life condition is excellent" and "So far gotten the important things" were excluded in the second table (Table 4). Here rest of the satisfaction statements were correlated with the three item scale sum results through reliability test (Table 4 ). Here the results show more relation with each other and results are greater 
than earlier which means that these three statements are more compatibly responsive and more correlated to measure of life satisfaction of the respondents during Covid-19 warlike situation. The Cronbach's alpha value is 0.839 now which is also greater than previous value (Table 4).

Table 2: Inter item correlation matrix (5 items)

\begin{tabular}{|c|c|c|c|c|c|c|}
\hline & $\begin{array}{l}\text { Life is } \\
\text { ideal }\end{array}$ & $\begin{array}{c}\text { Life } \\
\text { condition } \\
\text { excellent }\end{array}$ & $\begin{array}{l}\text { Satisfied } \\
\text { with life }\end{array}$ & $\begin{array}{l}\text { So far gotten } \\
\text { the important } \\
\text { things }\end{array}$ & $\begin{array}{c}\text { If life come } \\
\text { over, almost no } \\
\text { change needed }\end{array}$ & $\begin{array}{c}\text { Five item } \\
\text { scales sum }\end{array}$ \\
\hline Life is ideal & 1.00 & 0.611 & 0.577 & 0.460 & 0.565 & 0.828 \\
\hline $\begin{array}{l}\text { Life condition } \\
\text { excellent }\end{array}$ & 0.611 & 1.00 & 0.487 & 0.416 & 0.536 & 0.775 \\
\hline Satisfied with life & 0.577 & 0.487 & 1.00 & 0.472 & 0.535 & 0.777 \\
\hline $\begin{array}{l}\text { So far gotten the } \\
\text { important things }\end{array}$ & 0.460 & 0.416 & 0.472 & 1.00 & 0.506 & 0.726 \\
\hline $\begin{array}{l}\text { If life come over, } \\
\text { almost no change } \\
\text { needed }\end{array}$ & 0.565 & 0.536 & 0.535 & 0.506 & 1.00 & 0.809 \\
\hline Five item scales sum & 0.828 & 0.775 & 0.792 & 0.726 & 0.809 & 1.00 \\
\hline
\end{tabular}

It depicts that "Life is ideal"; "Satisfied with life"-" If life comes over, almost no change needed" these indicators are mostly connected to get a good satisfaction in livelihood condition during corona virus break out. And the Cronbach's alpha value is 0.839 now which is also greater than previous value (Table 4). Difference of these two matrices is to understand what indicators are more supportive to get more satisfaction in livelihood.

Table 3: Inter item Correlation matrix (3 items)

\begin{tabular}{lcccc}
\hline \multicolumn{1}{c}{ Attribute } & $\begin{array}{c}\text { Life is } \\
\text { ideal }\end{array}$ & $\begin{array}{c}\text { Satisfied } \\
\text { with life }\end{array}$ & $\begin{array}{c}\text { If life come over, } \\
\text { almost no change } \\
\text { needed }\end{array}$ & $\begin{array}{c}\text { Three item } \\
\text { scales sum }\end{array}$ \\
\hline Life is ideal & 1.00 & 0.581 & 0.565 & 0.837 \\
Satisfied with life & 0.581 & 1.00 & 0.552 & 0.859 \\
If life come over, almost no change needed & 0.565 & 0.552 & 1.00 & 0.681 \\
Three item scales sum & 0.837 & 0.859 & 0.799 & 1.00 \\
\hline
\end{tabular}

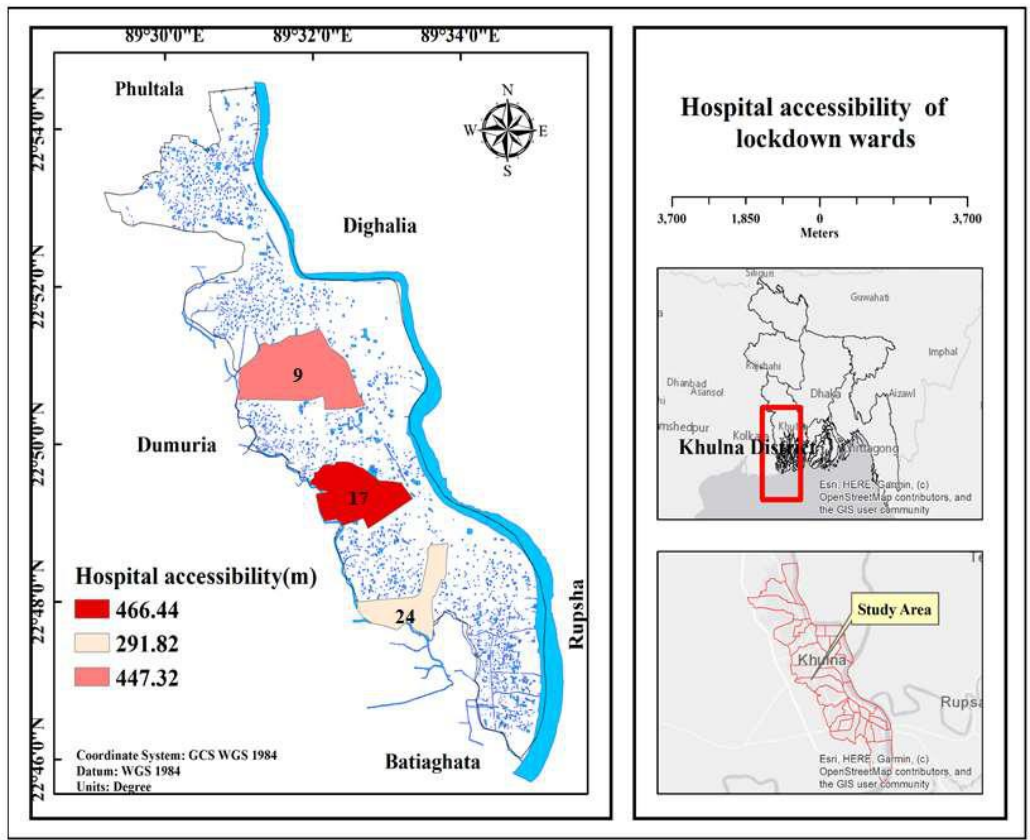

Figure 6: Hospital accessibility (Distance in meter from the centroid of each ward to nearby hospitals). 


\subsection{Accessibility of Nearby Hospitals}

The accessibility to the hospitals was analyzed using Arc GIS 10.5. The accessibility represents a scenario on the basis of how easily people get access to the hospitals. The spatial distribution of hospitals is analyzed by using the "Near tools". In this case the distance is measured by using Euclidean Distance in Arc GIS. But the actual the scenario was different. Ward no.- 17 is getting less accessibility to hospitals due to absence of nearby hospital at those localities. But ward no.- 9 is getting moderate accessibility. Ward no.-24 is getting good accessibility which represents a potential local area planning.

\section{CONCLUSIONS}

The aim of this research work was to explore how the COVID-19 puts its signature on socio economic condition in KCC. It was found that many citizens of $\mathrm{KCC}$ has been lost their jobs including day laborer, maid servant, private vehicle driver etc. Again, about $41 \%$ private driver and 39\% maid servant lost their income source due to many reasons. The respondents stated that they became unable to afford their maintenance cost, unused of private vehicle, maintenance of social distance were the main reasons for this suspension. To judge the satisfaction level of people during pandemic situation, a well-known index named Satisfaction with Life Scale was measured. From the survey data about 9 people expressed their strong dissatisfaction for the three statements such as "If I could live my life over, I would change almost nothing", "Satisfied with my life" as well as "In most ways, my life close to my deal". A reliability test was also conducted to test the inter correlation among five statements. Cronbach's value for five items was 0.808 which represents a good reliability. Among of the five statements, the two statements ("Life condition is excellent" and "So far gotten the important things") which show a lower correlation with sum of five items. That's why these two statements were rejected as well as the rest number of items was highly correlated with three item sum scales. Besides to assess the hospital accessibility in the locked areas of KCC, it had been found that ward no.- 24 which has more accessibility than other two wards. This research helps the other researchers to judge the impact of Corona on socio economic condition of overall of country as well as the local authority can find out which types of people needs help during lockdown moment consequently, they can provide govt. relief good properly. Besides during pandemic situation, the authority can identify which areas are deprived from health service as well as also put steps to provide health service properly.

The government of Bangladesh has already taken many steps to maintain the prevalence of COVID-19. The prime minister declared many financial packages which may cover of all classes people which is an important for those people who lost income source during pandemic situation. Despite of those initiatives, the study recommends some policy to recover the socio-economic crisis during Covid-19 in KCC:

- Improving socio-economic visibility. In educating customers about supporting small businesses and the solidarity economy, governments have a role to play. Online based shopping platform should be developed to sell various kinds of products including food products and other stationary products needed in daily life.

- Developing the necessary skills to run out the official works by sitting at home using telecommunications which would help not to shut down or less shut down the economic condition of the sectors with which the company is engaged.

- Distribution to social economy organizations of private safety supplies such as hand sanitizers and face masks, prioritizing those employed in the health and care sectors.

- The Tools to collaboration which help to encourage the society's economic partnership with other stakeholders, such as the private sector and residents. It also helps to support the development of volunteering platforms.

- Prioritization of inclusive coordination of different level stakeholders to develop urban agriculture during this pandemic to boost up local food security and economy for the marginal jobless people.

- Job retention and unemployment support system which help to enable the non-government companies specially to introduce short-term work schemes aimed at sustaining jobs in companies that have undergone a temporary decrease in demand for goods or services. Preserving jobs at companies help to access unemployment advantage and related income protection schemes.

- Local authority and NGOs can play an important role of risk communication through the professionals. This would help to prevent the misinformation and rumors about distressing pandemic. People suffering from socio-economic conflict including job crisis, maintenance of hygiene measures, psychological disorder and increased women violence due to long term isolation can recourse to the risk communication center for honest and transparent assistance.

- Deferral mechanisms for fees, contributions to social security and public land rentals. It is important for schemes that boost the cash flows of social economy organizations. Government should allow local taxes, VAT, income taxes and social security payments to be deferred for general people and organizations usually for three or six months.

- The relief goods should be distributed under the control of Bangladesh Army and local authority. 


\section{ACKNOWLEDGEMENT}

It is a matter of dignity and pride to express the heartiest gratitude, sincere appreciation and profound respect to Chinmay Prasun Biswas, Tax Commissioner (Rtd), Khulna for his encouragement, support and invaluable suggestions and constructive criticism throughout the study period. We are also profoundly thankful to Kazi Seerat, Abdul Fattah and Syed Riyadh Porthuhu for their valuable guidance, suggestions and advice to conduct the survey properly. The authors are grateful to the respondents of the study area who gave their valuable time for interview and their kind cooperation during the period of data collection. The authors are grateful to the Facebook group named Khulna Mart, Awareness and Update of Corona etc for collecting data in this study.

\section{REFERENCES}

Ali , S., and Nazrul S., 2020. Impact of Coronavirus on Livelihoods: Low- and Lower Middle-Income Population of Urban Dhaka, Light Castles, Available online: https://www.lightcastlebd.com/insights/2020/04/30/ impact-of-coronavirus-on-livelihoods-low-and-lower-middle-income-population-of-urban-dhaka (accessed on 30 April 2020)

Andrews, F. M., and Withey S. B., 1976. Social Indicators of Well-Being Americans' Perceptions of Life Quality, New York: Plenum Press.

Bangladesh Sangbad Sangstha, 2020. COVID-19 cases reach 15,602 in Khulna division, 10,513 recoveries, Khulna, BSS, Available online: http://www.bssnews.net/?p=438583 (accessed on 15 August 2020)

Barua, S., 2020. Understanding Coronanomics: The Economic Implications of the Coronavirus (COVID-19) Pandemic, Health \& The Economy Journal.

Diener, E.,1984. Subjective Well-Being, Psychological Bullelin, 95(03), 542-575.

Diener, E., Emmons R. A., Larsen R. J., and Griffin S., 1985. The Satisfaction With Life Scale, Journal of Personality Assessment, 49(1), 71-75.

Dineri, E., and Çütçü İ., 2020. The Covid-19 Process and the Exchange Rate Relation: An Application on Turkey.

Eichengreen, B., 2020. Coronanomics 101: which policy tools will contain the economic threat of COVID-19?, World Economic Forum, Availabe online: https://www.weforum.org/agenda/2020/03/coronaviruseconomics ( accessed on 12 March 2020).

Godman, B., 2020. Combating COVID-19: Lessons learnt particularly among developing countries and the implications, Bangladesh Journal of Medical Science, 19, 103-108.

Haque, M. N., Islam M. R., and Ansar S. B. 2018. Assessing the Water Supply, Sanitation and Waste Dumping Condition of Urban Slum: A GIS Based Approach, The Jahangirnagar Review, Part II: Social Sciences, XLII, 223-236.

Haque, M. N., Mamun M. A., Saroar M. M., and Roy T. K., 2019. Application of "DPSIR" Framework to Assess the Status and Role of Blue Ecosystem Services (BES) in Khulna City, Journal of Engineering Science, 10(2), 49-60.

IEDCR (Institute of Epidemiology, Disease Control and Research), 2020. Covid-19 Status for Bangladesh, Available online: https://www.iedcr.gov.bd/index.php/surveillance/212-nipahreport (accessed on 11 August 2020).

Islam, S. T., and Divadkar Y. N., 2020. How Bangladesh's leaders should respond to the economic threats of COVID-19, World Economic Forum.

Molla, H. H., 2020. 3 red zones in Khulna to be put under lockdown from 25 June, Khulna, Dhaka Tribune. Available online: www.dhakatribune.com/health/coronavirus/2020/06/23/3-red-zones-in-khulna-to-beput-under-lockdown-from-25-june (accessed on 23 June 2020).

Nicola, M., Alsafi Z., Sohrabi C., Kerwan A., Jabir A. A., Iosifidis C., and Agha R., 2020. The socio-economic implications of the coronavirus pandemic (COVID-19): A review, International Journal of Surgery, 185193.

Pavot, W., and Diener E., 1993. Review of the Satisfaction With Life Scale, Psychological Assessment, 5(2), 164172.

Pavot, W., Diener E., Colvin C. R., and Sandvik E., 1991. Further validation of the Satisfaction with Life Scale: evidence for the cross-method convergence of well-being measures, Journal of Personality Assessment, 57(1), 149-161.

Shammi, M., Doza M. B., Islam A. R., and Rahman M. M., 2020. COVID-19 pandemic, socioeconomic crisis and human stress in resource-limited settings: A case from Bangladesh, Heliyon, 6(5).

The Daily Star, 2020. 3 areas in Khulna to be lockdown from June 25, Khulna, The Daily Star, Available online: https://www.thedailystar.net/3-areas-in-khulna-be-locked-down-june-25-1918733 (accessed on 22 June 2020).

The Economist Intelligence Unit, 2020. COVID-19: The impact on industry, London: The Economist Intelligence Unit, Available online: https://www.incae.edu/sites/default/files/coronavirus-report-v4-1.pdf 
Truog, R. D., Mitchell C., and Daley G. Q., 2020. The Toughest Triage - Allocating Ventilators in a Pandemic, 382(21), 1973-1975.

UNDP (United Nations Development Program), 2020. COVID-19 pandemic Humanity needs leadership and solidarity to defeat the coronavirus, Available online: https://www.undp.org/content/undp/en/home/ coronavirus.html (accessed on 14 September 2020)

Zhu, N., Zhang D., Wang W., Li X., Yang B., Song J., and Tan W., 2020. A Novel Coronavirus from Patients with Pneumonia in China, 2019, New England Journal of Medicine, 382(8), 727-733.

(C) 2020 The Authors. Journal of Engineering Science published by Faculty of Civil Engineering, Khulna University of Engineering \& Technology. This is an open access article under the terms of the Creative Commons AttributionNonCommercial-NoDerivatives License, which permits use and distribution in any medium, provided the original work is properly cited, the use is non-commercial and no modifications or adaptations are made. 